\title{
Dizziness caused by meningocele-associated intracranial hypotension in neurofibromatosis type 1
}

\section{Figure Intracranial hypotension associated with large thoracic meningoceles in a patient with} neurofibromatosis type 1
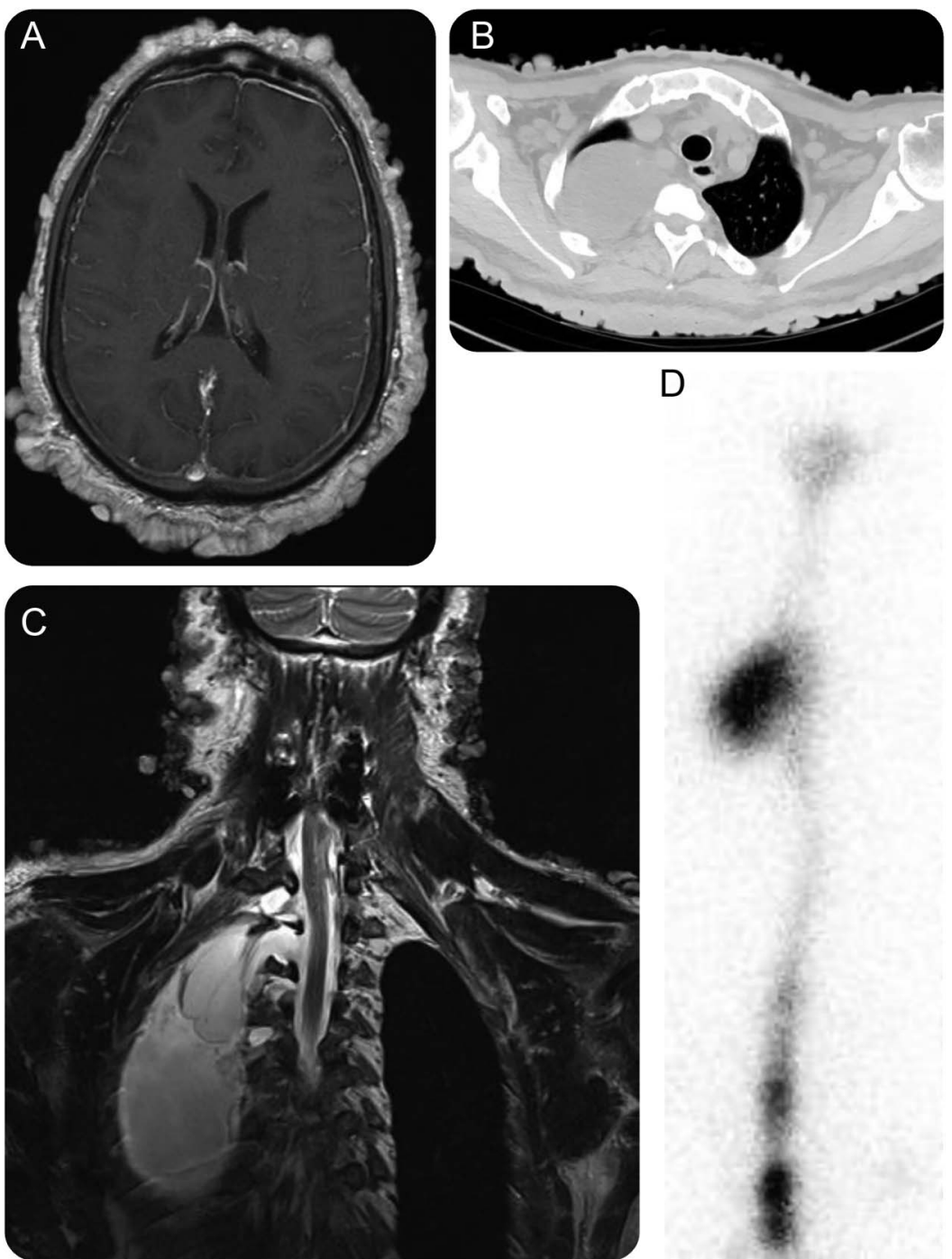

(A) Pachymeningeal enhancement seen on MRI T1 postcontrast sequence, with (B and C) several large meningoceles arising from the thoracic spine, (D) confirmed with radionucleotide cisternogram to be contiguous with the CSF compartment.

A 64-year-old man with neurofibromatosis type 1 (NF1) presented with falls caused by postural dizziness with negative prior workup including echocardiogram, telemetry, and tilt-table test. Neither discontinuing his $\beta$-blocker nor taking antihistamines, benzodiazepines, or antiemetics provided relief. Brain MRI demonstrated diffuse pachymeningeal enhancement (figure, A) and CT of the chest and MRI of the spine revealed large meningoceles arising from the thoracic spine (figure, B and C). Continuity of the meningoceles with cerebrospinal compartment was demonstrated with radionucleotide cisternogram (figure, D). Meningoceles are common in NF1 and can be mistaken as pleural effusions and lead to intracranial hypotension or tonsillar herniation if drained. ${ }^{1}$ Surgical intervention was considered but deferred because of difficulty in achieving dural 
closure with large meningoceles and complicated wound healing in NF1. With vestibular physical therapy, 6 months after hospitalization, he remained free of falls.

Lawren VandeVrede, MD, PhD, Rene A. Colorado, MD, Jong Woo Lee, MD

From the Department of Neurology, Brigham and Women's Hospital, Boston, MA.

Author contributions: Lawren VandeVrede: prepared manuscript and figure. Rene A. Colorado: reviewed and edited manuscript and figure. Jong Woo Lee: reviewed and edited manuscript and figure.

Study funding: No targeted funding reported.

Disclosure: The authors report no disclosures relevant to the manuscript. Go to Neurology.org for full disclosures.

Correspondence to Dr. VandeVrede: lvandevrede@partners.org

1. Huang TW, Huang HP, Ye QY, et al. A neurofibromatosis type 1 patient with thoracic encapsulated fluid and intracranial hypotension syndrome: a case report. Neurologist 2011;17:167-171.

\section{Save These Dates for AAN CME Opportunities!}

Mark these dates on your calendar for exciting continuing education conferences by the American Academy of Neurology. Learn more at AAN.com/conferences.

\section{Fall Conference}

- October 14-16, 2016, Las Vegas, NV, at the Cosmopolitan of Las Vegas

\section{Breakthroughs in Neurology}

- January 13-16, 2017, Phoenix, AZ, at the Sheraton Grand at Wild Horse Pass

\section{AAN Annual Meeting}

- April 22-28, 2017, Boston, MA, at the Boston Convention Center

\section{WriteClick ${ }^{\circledR}$ rapid online correspondence}

The editors encourage comments about recent articles through WriteClick:

Go to Neurology.org and click on the "WriteClick" tab at the top of the page. Responses will be posted within 72 hours of submission.

Before using WriteClick, remember the following:

- WriteClick is restricted to comments about studies published in Neurology within the last eight weeks

- Read previously posted comments; redundant comments will not be posted

- Your submission must be 200 words or less and have a maximum of five references; reference one must be the article on which you are commenting

- You can include a maximum of five authors (including yourself) 


\section{Neurology}

\section{Dizziness caused by meningocele-associated intracranial hypotension in neurofibromatosis type 1 \\ Lawren VandeVrede, Rene A. Colorado and Jong Woo Lee \\ Neurology 2016;87;1627-1628 \\ DOI 10.1212/WNL.0000000000003205}

This information is current as of October 10, 2016

\section{Updated Information \& Services}

References

Subspecialty Collections

Permissions \& Licensing

Reprints including high resolution figures, can be found at: http://n.neurology.org/content/87/15/1627.full

This article cites 1 articles, 0 of which you can access for free at: http://n.neurology.org/content/87/15/1627.full\#ref-list-1

This article, along with others on similar topics, appears in the following collection(s):

MRI

http://n.neurology.org/cgi/collection/mri

Vertigo

http://n.neurology.org/cgi/collection/vertigo

Information about reproducing this article in parts (figures,tables) or in its entirety can be found online at:

http://www.neurology.org/about/about_the_journal\#permissions

Information about ordering reprints can be found online:

http://n.neurology.org/subscribers/advertise

Neurology ${ }^{\circledR}$ is the official journal of the American Academy of Neurology. Published continuously since 1951, it is now a weekly with 48 issues per year. Copyright @ 2016 American Academy of Neurology. All rights reserved. Print ISSN: 0028-3878. Online ISSN: 1526-632X.

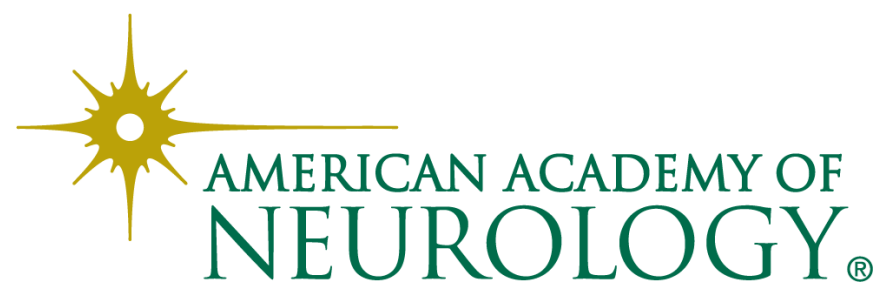

